Article

\title{
"True, Masculine Men Are Not Like Women!": Salafism between Extremism and Democracy
}

\section{Susanne Olsson}

Department of Ethnology, History of religions, and Gender Studies, Stockholm University, 11419 Stockholm, Sweden; susanne.olsson@rel.su.se

Received: 27 January 2020; Accepted: 5 March 2020; Published: 10 March 2020

\begin{abstract}
Whether we should understand Salafism in general as a security threat, as extremist, and as un-democratic and of concern to authorities is a debated question. In the article, this policy-oriented objective is addressed through an analysis of a specific non-violent Salafi ideology in Sweden, which is compared to the Swedish government's definition of gender equality. The basic argument in this article is that we can use words like "extreme" as relational concepts, which makes them analytically useful, i.e., when the benchmark is clearly defined.
\end{abstract}

Keywords: democracy; equality; extremism; gender; Salafism; non-violence

\section{Introduction}

Is non-violent Salafism in Sweden extremist, if compared to the Swedish government's definition of gender equality? Should academics use terminology such as "extremist" when referring to something Islamic (or religious)? These are the main questions addressed in this article. The basic argument in this article is that we can use words like "extreme" as relational concepts, which makes them analytically useful, i.e., when the benchmark is clearly defined. The argument in this article does not aim for a universal definition of any concept. The argument is rather aimed at academics who seem to become apologetic or uncritical when studying phenomena such as fundamentalist Islam/Salafism.

Salafi groups often operate in suburbs where the population is characterized by large percentages of inhabitants with an immigrant background. Several of these areas are noted for their social and economic segregation, with higher rates of criminality, gang related violence, and drug abuse. In these areas, state control is low, leaving a power vacuum. In such areas, some groups attempt to profile themselves as socially engaged with the aim to reduce violence and criminality, and to make the areas safer. Their focus on improving the suburbs is also an aspect, which such groups communicate to outsiders. This self-image is arguably a part of a strategic missionary work and an attempt to show outsiders (in the suburbs as well as, in some cases, representatives of the majority) that they are a contribution to society and that they should not be mistaken as Jihadis in any sense (Olsson 2019).

The article focuses issues that are usually not part of the image projected outwards by Salafis in Sweden, namely "democratic" issues. A reason why such issues is not publicly addressed is most likely that there have been critical comments from journalists and in social media on whether the Salafis in Sweden are undemocratic or not. One example is the hatred Salafis express towards Shiites that has been approached in one of the biggest Swedish dailies. Another example concerned whether studies at the Islamic University in Madinah should be granted student loans by the Swedish government, since the students are educated to become missionaries and this would be in contradiction to the Swedish state's neutrality in religious issues (Orrenius 2017a, 2017b).

This article analyzes whether non-violent Salafis are "extremist" and undemocratic in a Swedish context, and as such of possible concern to authorities. In order to do this, a specific Salafi website has been chosen, that is analyzed mainly related to its views on gender, which will enable an empirical 
foundation for the discussions in focus of the article. The website is darulhadith.com and it includes a large number of translations from Arabic to Swedish. The website should not be seen as representative for Salafism in Sweden or elsewhere. It is not clear who runs the site or if it has any external funding. It is not stated who is doing the translations. It is one of the largest Salafi websites in Sweden, considering the number of posts. Simultaneously, the number of visitors on the website is very low compared to other Swedish Salafi sites. ${ }^{1}$ Darulhadith does not belong to any formal organization. It is not funded by the Swedish state, and is therefore not subject to the state requirements of promoting and practicing democratic values. The Swedish Agency for Support to Faith Communities (n.d.) directly relates it financial support to democratic values:

The collaboration between the Agency and the faith communities enables discussion of issues relating to values, respect and tolerance. Within this framework, discussions and dialogues are organized about freedom of religion and the role and responsibilities of the faith communities in a democratic society. (Swedish Agency for Support to Faith Communities n.d.)

The website does not only portray itself as against Jihad and in detailing rules concerning ritual purity, but addresses all kinds of themes rather explicit, which is a reason for choosing it to exemplify with. Some translations seem to be highly irrelevant to a Swedish audience. ${ }^{2}$ It appears as if the person/s translating into Swedish simply translate everything they get their hands on. ${ }^{3}$

The main focus is how the official propaganda relates to gender equality, as it is defined by the Swedish government. Gender equality is thus used as analytical definition, and compared with the interpretation promoted on the website of Darulhadith. The short definition given by the Swedish government of "gender equality" reads as follows: "Gender equality is equality between women and men, who should have the same opportunities to shape society and their own lives. This area includes issues such as power, influence, finances, education, work and physical integrity" (Swedish Government n.d.a, https://www.government.se/government-policy/gender-equality/).

The Gender equality policy goals of the Swedish government are further elaborated and detailed:

The overarching goal of the gender equality policy is that women and men are to have the same power to shape society and their own lives. Starting from this objective, the Government is working towards six sub-goals: 1 . Gender equal division of power and influence. Women and men are to have the same rights and opportunities to be active citizens and to shape the conditions for decision-making. 2. Economic gender equality. Women and men must have the same opportunities and conditions as regards paid work which give economic independence throughout life. 3. Gender equal education. Women and men, girls and boys must have the same opportunities and conditions with regard to education, study options and personal development. 4. Equal equal [sic] distribution of unpaid housework and provision of care. Women and men must have the same responsibility for housework and have the opportunity to give and receive care on equal terms. 5. Gender equal health. Women and men, girls and boys must have the same conditions for a good health and be offered care on equal terms. 6. Men's violence against women must stop. Women and men, girls and

1 The material used in the article has been gathered within a larger research project on Islam in Sweden financed by the Swedish Civil Contingencies Agency (Myndigheten för samhällskydd och beredskap, MSB). The project addresses Wahhabi influences on contemporary Swedish Islam. The data collection, programing and analysis of traffic et cetera has been conducted by project participant Jonas Svensson, Linneaus University, Sweden.

2 One example of this, which was noted by Jonas Svensson, is the translation of a fatwa by Ahmad ibn Hanbal concerning whether one may throw a turtle directly into the fire, without slaughtering it first. (The answer was no) (https://darulhadith. com/skoldpaddskott/).

3 As has been discussed within the MSB-project, since the number of visitors to the website is low, one can perhaps understand the high translation activity as an activity of individual missionary work (da'wah), where the translator/s aims to spread the truth and makes it available to others. The study is not a reception study so such questions are left out. 
boys, must have the same right and access to physical integrity. (Swedish Government n.d.b, https://www.government.se/government-policy/gender-equality/goals-and-visions/)

In the following, a discussion on various perspectives on Salafism related to securitization and extremism is presented, in order to analytically frame the article. A brief note on the Saudi context is made, to situate the scholars used as authorities in the group. The Darulhadith website is presented and a presentation of the empirical material is made, structured according to the topics of the article. The views on gender roles in general, the forbidding of gender mixing, and what places that are considered appropriate or not for women to be in, are the main examples addressed. The article ends with a critical discussion relating to the initial question whether the website can be designated as extremist or not and includes a general reflection on the academic language related to Salafism.

\section{Salafism on Creed and Deed}

Regarding theology, it is possible to generalize and state that Salafis share a common creed ('aqidah), while views on programs for action or methodology differ. This includes the promoted approach to the sources in terms of interpretation as well as actual behavior, which includes rituals and everyday life conduct. Considering theology, as a result of the literalist stance among Salafis, metaphorical readings are rejected and texts must (ideally) be accepted at face value (Wiktorowicz 2001, pp. 114-15). For a thorough outline of the delineating features of a Qur'an-Sunnah hermeneutics among Salafis, see Duderija (2011b).

An often-used typology of Salafism has been formulated by Quintan Wiktorowicz and it explicitly focuses on the different Salafi views on accepted methods of action. He divides Salafis into: (1) Purists, who are Salafis focusing on a practice of non-violence, purification and education, and often stress segregation and isolation as methods; (2) Politicos, who argue that political participation as a method to reach the aims is allowed; and lastly (3) Jihadis, who are militant, calling for a change through violence and revolution. Wiktorowicz states: "All three factions share a common creed but offer different explanations of the contemporary world and its concomitant problems and thus propose different solutions. The splits are about contextual analysis, not belief" (Wiktorowicz 2006, p. 208). See also Meijer (2009a) on various case studies on global Salafism. Considering the website in focus of this article, it is distinctly puritan.

The relationship between puritan Salafis and other types have been discussed, where one question has concerned whether the puritan type may be utilized to counter more militant or radicalized Salafism. This has been questioned by some scholars who hold that secular agencies ought not to engage in theological discussions and that if they do, they may unintentionally give "credibility" to specific groups. Moreover, scholars have warned that the puritan discourse, which promotes social conservatism, may lead into further radicalization and an acceptance and use of violence, or that it at least is an ideology at odds with democracy and thus still causes a threat, disregarding the anti-violent rhetoric that is often explicitly projected outwards (Roex 2004; Schmid 2014; Wagemakers 2012).

Set in the discussion on securitization of Islam, we can relate these discussions to the overarching issue of accommodation of Islam in Western contexts, which is considered a challenge in several European countries, seen for example in different national laws on Muslim female dressing and control of mosques and imams (see Cesari 2009). The perceived threat of Islamic terrorism has affected national policies as well as laws on immigration and terrorism. Such changes may cause the general public to become more suspicious of Muslims, and discrimination of Muslims have also increased, due to the widespread view of Islam as an alien and dangerous religious tradition (Cesari 2009, pp. 11-13). Cesari argues that: "European discourse on Islam is a microcosm of the debate on Islam's compatibility with the West" (Cesari 2009, p. 1).

This article can in a sense be regarded as a part of this larger debate and therefore a further comment is deemed necessary to make. Green relates that a criticism which is often directed to the concept of Islamophobia is that the use of the concept risks suppressing freedom of speech and limit the critical discussions on religion. He asks: "Is there a risk that anyone who criticizes Islamic belief 
and practices is automatically labeled an Islamophobe?" (Green 2015, p. 20). Green asks what criteria we ought to use in order to distinguish between Islamophobia and legitimate criticism. He stresses that we must avoid generalizations and hate speech, and that our criticism should not cause actions that undermine the freedom of religion for Muslims or their equal opportunities. Moreover, he also stresses that "Islamophilia", the drive to present "good" Islam and "good" Muslims as ideal images in order to counter Islamophobia, is not a solution (Green 2015, pp. 22-27). The argument in this article is that we should be able to use critical concepts such as "extremism" without being accused of being Islamophobic, and that the way to do this is to use a clearly defined analytical terminology.

\section{Are Salafis Extremists?}

What is the backdrop situation to the issue discussed here and why is it important to discuss? One aim of this article is to discuss the use of concepts related to Islamic fundamentalism (understood as an interpretative approach to Scripture). Research shows that the use of terms such as "radical" related to Islam in media may lead to an increase of hostile Islamophobic attitudes and practices as well as stereotyping of Islam and Muslims, since "radical" is often understood to be equal to terrorism, which increases support for policies targeting religion (Hoewe and Bowe 2018, pp. 2, 15). See Green (2015) for a critical discussion of the term Islamophobia). Terminological use may therefore have far-reaching consequences. To be a responsible scholar, one must therefore reflect on the possible consequences of research results, but this should not lead us to be uncritical, apologetic or to avoid certain topics. We must be allowed to ask whether certain religious interpretations may lead to undemocratic consequences.

There is an on-going discussion whether Salafism constitutes a threat to democratic values. Related questions are if Salafism as a whole constitutes a security threat. What about those Salafi groups that promote Islam as a non-violent religion and actively work against the use of violence, distancing themselves from Jihadism. Should we be scared of all Salafis in Europe? (Roex 2004, p. 51). Are violent and non-violent extremism merely two sides of the same coin? (Schmid 2014). Anthropologist Roex, for example, holds that it is important to distinguish between different Salafi types in terms of security policy and holds that it is problematic to present Salafism by definition as a security threat and a threat to democracy (Roex 2004, p. 51).

Others consider non-violent Salafism merely as a "conveyor belt" into violently inclined extremism (Schmid 2014, pp. 2, 16). From this perspective, Salafi teaching in general is described as anti-democratic and anti-integrative, posing a threat to democratic rule. Salafism from this perspective supports isolationism, enclavism and exclusivism. Schmid, a scholar in terrorism studies, argues that the

fundamentalist value system is extreme by the prevailing norms of West European societies and widely considered incompatible with core principles of modern liberal-democratic societies such as the separation of state and religion, popular sovereignty, gender equality, respect for minority rights and acceptance of laws decided upon by a majority of people. (Schmid 2014, p. 15)

Here, even purist Salafis, striving to increase piety and rejecting violence, are considered extremists. They have maximalist goals and their peaceful da'wah (mission) functions as a strategy and a tactical choice to push their Islamic and undemocratic agenda (Schmid 2014, p. 18). In the Merriam-Webster dictionary, "extreme" is defined as something "exceeding the ordinary, usual or expected" (Extreme 1986). It is not the case that all "unusual" behavior should be understood as extreme. What is considered unusual or uncommon is related to the context where it is decided. Several things may then be regarded as extreme, but not extremist in the sense of violent or destructive, for example bungee jumping. Another definition of "extremism" is "willful deviation from the norms of conduct in a given context or situation. Such norms describe what most people in a given society would do in the same circumstances" (Kruglanski et al. 2017, p. 218). 
The term is here related to democracy. The view "that extremists are always wrong aptly summarizes the majority opinion in democratic societies" (Mudde 2016, p. 57). "Extremism" is often used intertwined with other terms having negative connotations, such as fanaticism, and it is explained and defined related to "democracy" (Mudde 2016, p. 58). Extremism is in this respect understood as authoritarian and anti-democracy, where "extremists oppose the ideal and system in which the majority of the people decide upon their own rulers" (Mudde 2016, p. 58).

It is a fact that not all Salafis advocate violence or actively work against democracy. However, their ideologies, or practices, may still be characterized as authoritarian and "extremist". Considering the minority Muslim Salafis in Europe, their stance towards society does not conform to mainstream outlooks on democracy, and may in this regard be designated as extreme. "Extremism" is a relational concept and what is designated as extreme refers to something that is strongly contradictory to what is defined as the norm. To use "extremism" as an analytical term, we therefore need to define the "benchmark", i.e., what we regard to be "mainstream" or "normal", to compare with (Schmid 2014, p. 11; Berger 2018, p. 2). The terms "radical" or "radicalized" Islam, will be avoided in this article, due to the definition of "radical" as an often open-minded egalitarianism, compared to "extremism" as close-minded and supremacist (Schmid 2014, pp. 12, 14-15). We need to acknowledge that these terms are relational concepts. What is designated as extreme or radical thus refers to something that is not regarded as a norm in a specific context. The following citation from Mandel illustrates this relational aspect of concepts, which is a perspective that is forwarded in this article as well:

The modern concept of radicalization would thus appear to support a form of relativist thinking about socio-political events and actors related to the problem of terrorism. To be radical is to be extreme relative to something that is defined or accepted as normative, traditional, or valued as the status quo. The relative notion is important in the present context because it indicates that agreement on what is to be defined as radical may be subject to "perspective effects". That is, what one group may regard as radical forms of thought and behavior may not be seen as radical by the purveyors of those forms of though and behavior. (Mandel 2009, p. 105)

From this background, it is not surprising that governmental agencies define radicalization as a threat to the existing order, and often related to "extremism": "The relative notion of extremism, including the threat to the existing order posed by extremism, is evident in some governmental attempts to define radicalization" (Mandel 2009, p. 106).

Based on the above, it means that when speaking of gender equality, the definition from the Swedish government is followed. That is the stipulated norm, or benchmark, to which "extreme" is related in this article. To be very clear, the claim is not that the Swedish government's definition is a universal definition, but it is the definition used in the national context to which the website is compared.

In The Edge of Violence, the authors hold that some (intolerant) forms of social and political activism may represent a social threat, or even a long-term threat to the democratic order (Bartlett et al. 2010, p. 38). Lowe problematizes this illustrating the problem of deciding when a view actually becomes a social (or security) threat, in referring to Sedgwick who holds that groups supporting violence, but that do not encourage it, are part of a security threat since they constitute a supportive environment ((Lowe 2017, p. 923), referring to (Sedgwick 2010, p. 490)).

Lowe has discussed terminology and the use of "extremism" in the United Kingdom. Lowe argues for the need to develop a definition of "extremism" in order to avoid stigmatizing everyone and to ensure "that individuals in society can still express radical views opposing accepted political and social norms without being considered an extremist who is being drawn into terrorism (Lowe 2017, p. 918). As Lowe stresses, it is important that "legitimate political dissent and healthy radicalism" is allowed and encouraged (Lowe 2017, p. 925). He therefore calls for a separation between what he calls "non-violent extremism" and "not-violent activism" (Lowe 2017, p. 923). Not-violent activism 
"is seen as opposing views (including strident opposing views) where the activist accepts that in a pluralist society change can only be achieved through constitutional principles under the rule of law" (Lowe 2017, p. 925). Nonviolent extremism is still of concern, due to the undemocratic stance. This leads Lowe to suggest the following definition of "extremism":

Extremism, be it through violent or non-violent means, is a vocal or active opposition to the United Kingdom's constitutional principles, the legal principle of the rule of law and the existence of a pluralist society that is manifested by advocating an intolerance of an individual's rights and freedoms, and, different faiths and beliefs that encourages discord in society. (Lowe 2017, p. 927)

I suppose that most of us accept that there are forms of activism that are "not-violent" that are healthy and should be allowed in a liberal state. Let us then turn to the phrase "nonviolent", which could then still be considered as a part of the definition of "extremism". The message on the website is a case of non-violent extremism, which will be illustrated below, and the term extremism is valid to use analytically. Following the thematic presentation of the material, the issue of terminology will be returned to in the concluding section where the themes addressed in this section will be problematized further.

\section{A Note on Salafism and Saudi Arabia}

Before presenting the material, a brief comment on Saudi Arabia will be made, for the reason that the Saudi scholars referred to on the website are taken out of their own Saudi context. The material used below all concerns gender issues and they are produced by Saudi scholars who obviously live in a very different context than Sweden. Wagemakers discusses gender-mixing in Saudi Arabia and presents religious arguments among Saudi Salafi scholars. He shows that the conservatism usually associated with Salafism is the case, but that there are several nuances and that there are even cases where Salafi scholars are in favor of gender-mixing. The different views that he presents are related to the debates on reform in Saudi Arabia, where gender segregation is the norm (Wagemakers 2016, pp. 40-51). The situation for women in Saudi Arabia has not only been formed by Wahhabi ideology, but also to actual circumstances, such as the need for labor during the oil exploitation in the 1950s. However, the religious identity of Saudi Arabia makes gender issues symbolic and "women issues" are in focus. Moreover, the oil has contributed to the wealth of the population, leading to less women working and more families hiring servants taking care of the household. Thirdly, the religious community has always had a limited access to power, and the state has given the scholars influence over social and personal matters instead. This, Wagemakers argues, has caused them to focus on minor doctrinal issues, such as gender relations (Wagemakers 2016, p. 42), see also al-Rasheed (2013); Meijer (2019b); and Le Renard (2008).

Salafis relate to the phrase al-walā' wa al-barā' to argue for loyalty and disavowal, where a rejection of imitating unbelievers can be a strategy. However, Salafis often use the rhetoric of "us" versus "them", where everything, real or imagined, "Western" is rejected, such as gender-mixing (Wagemakers 2008). This aspect of Salafism can be seen in Saudi Arabia in both ideology and in practice. Ethnographic work among Salafi women in minority situations exist, and there is research on minority Salafi views on gender, where a rhetoric similar to the on found among scholars in Saudi Arabia are found, mainly from the more conservative section (Inge 2016; Olsson 2019). There are also some in-depth analyses regarding the construction of gender roles, such as the ideal "Muslim woman" from Salafi perspectives (Duderija 2011a), or modern juridical responsa related to gender, leading to a construction of gender roles within a highly patriarchal framing (Abou El Fadl 2001), or those accommodating to pragmatic and human rights perspectives (Duderija 2011a). The title of one book, Constructing a Religiously Ideal "Believer" and "Woman" in Islam. Neo-Traditional Salafi and Progressive Muslims' Methods of Interpretation, illustrates the constructivist nature of different contemporary Islamic interpretations regarding gender, 
where the so-called progressive Muslims adapt Islam to a framing of equality and human rights, which is not the case considering Salafis (Duderija 2011a).

The scholars used at the website in focus of this article are part of the contemporary Saudi context and the debate on gender-mixing. At the website Darulhadith, their ideas are simply translated and published without any reference to the Saudi context or the debate. It could therefore be seen as taking a stance in the Saudi debate, but that question is not part of the purpose of this article. Moreover, the website mainly uses contemporary Wahhabi scholars, which is apparent in the topic of gender issues. The website also uses older sources from scholars in the Hanbali tradition concerning some topics. However, now we know where the translated material stems from and we can move to the Swedish website.

\section{The Group in Focus}

The Darulhadith promotes living a segregated life. Emigration to a Muslim country (hijrah) is also promoted. For example, several published texts refer to hijrah, based on the opinions of the Saudi scholar al-Fawzān, who is considered an authority (http://www.darulhadith.com/v2/category/fiqh/hidjrahutvandring-fran-ett-otroget-land-till-ett-muslimskt-land/al-fawzan-om-hidjrah/). Furthermore, violence as a method is rejected, and it distances itself from violently inclined groups. This is a strategy to define borders between in-groups and out-groups and to set the standards of acceptable behavior. One illustrating citation in this regard is the following: "Only ignorants like Hizbiyun use violence. Ahl-us-Sunnah does not use violence. We challenge those who say that Ahl-us-Sunnah uses violence without proving it" (translation: Darulhadith.com. published on 17 January 2017. Allāmah Muqbil bin Hādī al-Wādi'î̀ (d. 1422); source: Tuhfat al-mujīb: 206-7. http://www.darulhadith.com/ v2/vi-ar-inte-i-behov-av-vald). They reject the Islamic State and other violent groups since they are considered khawārij (http://www.darulhadith.com/v2/har-isis-tagit-makten-via-militarkupp/). On khawārij, see Della Vida (2012). On the contemporary usage of the term khawārij, see Wagemakers (2009). The website has a long list of what they regard to be infidel groups and people. The promoted treatment of such groups and individuals are normally avoiding them (Olsson 2017). This is similar to many other Salafi oriented sites and publications in Sweden.

One thing that is noticeable and a reason why this particular site has been chosen is that it is much more explicit than other Swedish Salafi websites regarding some "difficult" issues, such as views on gender. Other groups with public websites do present fatāwa and lectures concerning the "Woman Question", but they are often rather vague and avoid many issues that could be considered controversial by the majority population (Olsson 2019). This is strategic in the sense of avoiding unwanted attention. It is surprising that Swedish journalists and scholars did not put this website in focus, and instead focused on other groups. One reason is likely that it is difficult to find contact information and the more proactive groups who are very active in social media and like to gain attention are much easier to catch. Moreover, it has more than 20,000 posts that are organized with subheadings, making the material on the website unusually large and very well structured for research.

The material used in this article are from the heading: "Women related (issues)" (Swe: kvinnorelaterat). It has four separate subheadings: Family; Ibadah; Clothes and decoration; Society. The focus is on the material published under the subheading "Society". As we shall see, this concerns gender roles in areas such as the family, work, public transport, dress, and childcare.

\section{The Importance of Preserving Gender Roles}

Most of the texts presented at Darulhadith are in the form of fatāwa or Friday sermons. Several stem from well-known shuyūkh operating in a Saudi context, such as al-Fawzān (b. 1933), al-Madkhalī (b. 1931) and Ibn 'Uthaymīn (1929-2001). All of them would reject violence as a method and also rebellion against the political leaders. Most texts published include clear references to the Arabic source, in the form of texts of audio/video links. All are translated into Swedish.

I will begin with a citation that illustrates the dominant view: 
Questioner: A caller (to Islam, a missionary) said that there is no difference between men and women...

al-Fawzān: (To) men like him, no! But true, masculine men are not like women: (As stated in the Qur'an) "the male is not as the female" (Q3:36. All references to the Qur'an follow the translation of Pickthall 1930. http://www.darulhadith.com/v2/det-finns-ingen-skillnadmellan-man-och-kvinnor/).

Al-Fawzān is frequently used as an authority on the website. In this citation we can note how he establishes a clear difference between men and women, stressing masculinity, based on the Qur'an. Ibn 'Uthaymin too is occupied by masculinity. For example, he notes that it is forbidden for men to wear silk, but for the "poor woman" it is allowed since she is in need of something to make herself beautiful with; "For the man it is enough that he is manly" (http://www.darulhadith.com/v2/tva-avkvinnans-specifika-drag/).

Ibn 'Uthaymīn also states that it is necessary to differentiate between justice and equality. Equality is not considered Islamic. Rather, the Qur'an in his view rejects equality between men and women, but it confirms justice. He explains that to be equal, a son and a daughter would inherit the same (which is against the will of God). To be just means that each get what they deserve (according to God's will) (http://www.darulhadith.com/v2/ingen-jamstalldhet-i-islam/).

In a longer text from a khutbah by al-Fawzān, given the title "a message to the woman" on the website, al-Fawzan states that one of the most serious questions today is what he calls "the Woman Question". In a rather conservative fashion, he states that women and men both have great duties in this life, and that each gender has its own duties, which is necessary in order to have a balanced and functional society:

And if each group sticks to its duty and fulfils it, the society will reach great goodness. If the order would be shaken, a tremendous deficit will occur, just as what you heard about the role of the woman during the heathen time, her role in today's infidel countries as well as her role among the religious Muslims. (http://www.darulhadith.com/v2/ett-meddelande-till-kvinnan)

Al-Fawzān stresses that "the woman" is very important. He explains that that is the reason why the Prophet during his farewell sermon said: "Take good care of the women. They are your prisoners" (see also sunan Ibn Majah, "I enjoin good treatment of women ([astawșū bi a-nisā' khayran), for they are prisoners ('awānn) with you". Vol. 3, Book 9, hadith 1851; Arabic reference: Book 9, hadith 1924; https://sunnah.com/ibnmajah/9). Al-Fawzān refers to the Prophet's order to take care of women, because they have an important role in society. This means, in his explanation, to treat them well and give them their rights. He then states: "it is obligatory, but it is even more important to protect them from indecencies-the woman is weak — and (to protect them from doing) what they want." This is "proved" by a verse from the Qur'an: "Men are in charge of women, because Allah hath made the one of them to excel the other, and because they spend of their property (for the support of women). So good women are the obedient, guarding in secret that which Allah hath guarded" (Q4:34).

Al-Fawzān states that this responsibility on behalf of the man does not only mean justice and (economic) support. Even more important is that he protects the woman from getting lost, from liberating herself, and from taking shyness and chastity easily. In the verse just cited, al-Fawzan explains that "man" means not only husband, but also father, brother, or other male guardian (http://www.darulhadith.com/v2/ett-meddelande-till-kvinnan/). If things go so far that the woman needs punishment, that too is his responsibility, in accordance with the Qur'an: "As for those from whom ye fear rebellion, admonish them and banish them to beds apart, and scourge them" (Q4:34). Al-Fawzān states: "Thus, the woman is in need of supervision" (http://www.darulhadith.com/v2/ettmeddelande-till-kvinnan/).

Having conducted this analysis of the relationship between men and women, based on the Qur'an and Sunnah, al-Fawzān turns to explain what the world looks like today. This has already been seen in 
a citation above, where he refers to the role of women during "heathen time" (prior to Islam) and in "today's infidel countries". He states that in the contemporary world, the enemies of Islam focus on the "Woman Question", since they know it is the most important question in society. He states that these enemies consider chastity as humiliation of women, that such a woman has been bereft of her freedom. Instead, he explains, that is when her freedom is preserved. She can then freely obey the orders of Allah, raise her children and fulfil her divinely given responsibilities. He says: "She is a shepherd in her husband's home and responsible for her flock. This is her true freedom." In the same khutbah, he compares this ideal image with what assumingly is how he considers that enemies behave and address as freedom: "Concerning her freedom in nakedness, indecency in front of other people, flirty walking in stores and the ability to go wherever she wants, that is slavery and not freedom. That is the slavery of temptation and Satan." To prevent this kind of "slavery" and society from falling apart, he holds that women must be protected:

We must keep our women among the wives, daughters and relatives. We must cooperate to protect them and avoid listening to this propaganda. The unfaithful attempts to extinguish Islam in all manners possible. The largest way is to extinguish the woman. Because the woman is that cornerstone of the family and the home. If she is destroyed, the home and family are destroyed. The daughters will be destroyed when imitating their destroyed mothers and relatives. Thus, we must guard our women. (http://www.darulhadith.com/v2/ ett-meddelande-till-kvinnan/)

The enemies, the unfaithful, are clearly considered a threat to Muslim societies and the division of roles between men and women that he promotes. Al-Fawzān states that men and women have their designated work, which leads to a balanced society. If this order would fall, society will be flawed. He argues that this is the reason why the Prophet cursed masculine women and feminine men (Ibn 'Uthaymīn too refers to this and states that men imitating women, or women imitating men, are cursed. http://www.darulhadith.com/v2/sa-overtraffar-mannen-kvinnan/). This, al-Fawzān explains, was intended to preserve the woman and let her remain in her "natural nature, religion, character, and honor" (http://www.darulhadith.com/v2/ett-meddelande-till-kvinnan/). Ibn 'Uthaymīn too is used in this respect, commenting on a "disaster" that has appeared. Namely, women have begun to wear pants! If they begin using wide pants, they will end up using tight pants with skin color so that they look naked and expose themselves. Moreover, wearing pants makes a woman look like a man, something that the Prophet cursed (http://www.darulhadith.com/v2/ibn-\%c2\%b4uthayminsfredagspredikan-om-konens-jamstalldhet/).

Al-Fawzān is repeatedly used on the website concerning the status of women. He is used to confirm the ideal image that women are honored and have a status in Islam, as compared to the women of the so-called infidels. In this next citation, the enemies are explicitly categorized as "Westerners":

Concerning the women of the infidels, disregarding if it is the old heathens or todays, she is only an enjoyment. Everyone enjoys her. She is like a toilet. Everyone goes inside, fulfills their needs and goes out. She is like a toilet. Others quench their needs on her and leave her. So, the status of the woman in the infamous societies lacks religion and honor. Evil missionaries want us to join Western society on all issues. They want to make her become like Westerners. (http://www.darulhadith.com/v2/toalettkvinnan/)

Several of the texts published seem to be aiming at presenting ways to prevent societal collapse. The enemy is some vague "Western" liberalism. The "they" are always set up as a contrast to true Islam. One example is shown in a question that appears very important to prevent societal collapse, and that is to avoid fornication, adultery. Al-Fawzān refers to the Qur'an: "And come not near unto adultery. Lo! it is an abomination and an evil way" (Q17:32). This, al-Fawzān explains, means that Muslims should avoid everything that leads to fornication. Examples given on how to prevent fornication is that women must be covered, and not travel without mahram, that she does not mix with men in offices, clubs, parties, and even on the TV-screen or media. 
She shows herself beautiful and with make-up on TV with a man as if she were his wife. In front of the whole world and not in front of two or three people. Should a Muslim woman face the whole world in this way? It is ugly and bad. (http://www.darulhadith.com/v2/tyglakvinnan-for-att-forhindra-otukt/)

Al-Fawzān also refers to ahädìth to support his opinion that women are not allowed to travel without mahram, or to be alone in a room with a man who is not mahram. He also refers to the Prophet who forbade women to intermingle with men. This, he states, explains why women should pray behind men, covered. This is regarded as a proof that intermingling with men is forbidden too. In extension, he asks-what about women intermingling at offices, parties and the market, and states that this is a very serious question, especially now when they are surrounded by enemies and ideological warfare (http://www.darulhadith.com/v2/ett-meddelande-till-kvinnan/). This dual image of the world, the division between the good/us-bad/them, is a common and foundational strategy to portray the world among Salafis, and to explain the threat to Islam/Muslims, and to motivate a specific behavior and specific gender roles.

\section{Forbidding Gender Mixing}

Based on bin Bāz, it is concluded that it is not allowed to shake hands with any (unlawful) woman, disregarding their age. This is based on a hadith where the Prophet reportedly said that he did not shake hands with women (http://www.darulhadith.com/v2/far-man-skaka-hand-med-det-motsatta-konet/). Al-Albāni refers to a hadith saying it is better for a man to be struck by an iron needle in the head than touching an unlawful woman (http://www.darulhadith.com/v2/battre-att-fa-en-jarnnal-i-huvudet).

Al-Albāni is used to address the question if women are allowed to go by public transport to work. Al-Albāni states that it is allowed only if there is no mixing with men, and if it is certain that she will not be kidnapped, and if it is not (merely for the sake of making) a trip (http://www.darulhadith.com/v2/al-albani-om-att-kvinnan-fardas-i-offentliga-transportmedel/).

Mixed work places are not allowed. One example is based on al-Fawzān who states that it is not allowed to work in a hospitable where genders are mixed, even if one lowers ones gaze (http://www.darulhadith.com/v2/arbete-pa-beblandat-sjukhus/). Moreover, mixed schools are seen as during the heathen times (based on Muqbil bin Hādī al-Wādi'îi) (http://www.darulhadith.com/v2/ beblandade-skolor-hor-till-den-hedniska-tidens-drag/). Al-Fawzān is used to state that one should move to a country where there is no gender mixing if one must work in gender mixed environments in the country where one lives (http://www.darulhadith.com/v2/beblandning-pa-alla-arbetsplatser/). Al-Fawzān calls it a disadvantage and an "evil" if women leave their homes and work together with men (http://www.darulhadith.com/v2/kvinnans-uppgift-ar-att-ta-hand-om-hemmet-och-barnen/). He states some reasons to this view that appear in the following citations, where we can see how he considers women to be quite different from men, and weaker than men due to biological reasons, and he warns about societal collapse if gender roles are changed:

First of all the woman must do something that she cannot handle. She cannot cope with the work of a man. She has her monthly period. She is pregnant. She cannot cope working in the sun with the man. She cannot stand high heat or strong cold. She cannot cope to travel like a man. In spite of this they say that the woman should travel alone. ( ... ). (http: //www.darulhadith.com/v2/kvinnans-uppgift-ar-att-ta-hand-om-hemmet-och-barnen/)

Secondly, the home will fail. Nobody is in the home to take care of it. The home is in need of the work of a woman. Who shall work in the home if she leaves it? Nobody can do the work of a woman in a home. Men do not do the work of a woman in the home. The women do not do the work of men outdoors. Allah has given each one suitable duties. (http: //www.darulhadith.com/v2/kvinnans-uppgift-ar-att-ta-hand-om-hemmet-och-barnen/) 
Ibn 'Uthaymin too confirms that women are weaker than men in stating that jihād is obligatory only for men, not women: "Because the woman is weak and cannot cope to participate in war" (http://www.darulhadith.com/v2/kvinnan-ar-inte-som-mannen/).

In describing the "they" that al-Fawzān often refers to; those who want women to work and behave like men - the following citation further shows the disastrous effects on society that would occur if women began to behave as the enemies promote:

However, the hearts of these people of turned backward and therefore there thinking also is. They are blind. When the woman goes out, the home that Allah has made her place is ruined. Allah has made the home the place where children lives. The man comes there after work. If the man comes home after work and finds an empty and messy home his condition will be deteriorated. It affects his psyche negatively. The biggest ruin affects the children however. Who is at home to raise the children? The children is left alone, without any one to bring them up. They grow up like animals and are pushed to other people who will raise them. These people do not have affection for the children. They do not care about them. It does not bother them whether or not the children becomes good or bad because it is not their children. Should they perhaps send them to nursery? That is even worse. The children only has the mother to raise them and feed them. That is the duty that Allah has created her for. (http: //www.darulhadith.com/v2/kvinnans-uppgift-ar-att-ta-hand-om-hemmet-och-barnen/)

Moreover, al-Fawzān holds that it is obligatory for women to cover. If a husband orders a woman to cover, he is enjoining what is correct, he states. The same goes for women speaking with a loud voice. That is not allowed, since the voice of women often is tempting (http://www. darulhadith.com/v2/kvinnan-skall-inte-hoja-rosten-i-frammande-mans-narvaro/). He also states that if a woman has a tempting voice, it is considered to be 'awrah (i.e., the part of the body that should be covered by clothes) (http://www.darulhadith.com/v2/den-muslimska-kvinnan-enbevarad-parla/). Ibn 'Uthayminn states that the voice of women are not 'awrah per se, but her voice can be tempting. This is why she should clap her hands, while men can say "Subhan Allah" (http://www.darulhadith.com/v2/mer-an-200-skillnader-mellan-mannen-och-kvinnan/). To be alone with a male stranger (not mahram) is of course not allowed. That would lead to indecency. He states (based on al-Tirmidhī (1171)) that a "man is not alone with a woman without Satan is the third" (http://www.darulhadith.com/v2/enrum-en-orsak-till-oforskamdheter/).

\section{The Place for Women Is Their Home}

Al-Fawzān is again used to confirm that the place for women is in their home and that they should cover. Answering accusations that Muslim women are oppressed, he states that women are protected and honored by the veil. "That is purer for your hearts and for their hearts" (Q33:53. http://www.darulhadith.com/v2/den-muslimska-kvinnan-en-bevarad-parla/).

Moreover, women should stay in their homes, according to al-Fawzān: "And stay in your houses" (Q33:33). This is interpreted as an honor and protecting of the woman. This means, he argues, that she can avoid fatigue and difficulties. "She has enough work in the home. There are works in the home that only women can perform. How can they say that staying between the four walls of the home is a disgrace to her, when God said to the purest women in the world, the wives of the Prophet (sas): "Bedizen not yourselves with the bedizenment of the Time of Ignorance" (Q33:33). The Swedish translation adds: (if you must leave it), i.e., the home. Al-Fawzān holds that the shyness of a woman is to her honor and it is a way for her to get her full rights. It protects her freedom, he states. Furthermore, the veil protects women from being molested It is seen as a purity for the heart and a protection. The Qur'an is used as proof: "Prophet! Tell thy wives and thy daughters and the women of the believers to draw their cloaks close round them (when they go abroad). That will be better, so that they may be recognised and not annoyed. Allah is ever Forgiving, Merciful" (Q33:59). This is contrasted with how women are treated among "infidels": 
She is a toy in the hands of the sinners, as long as she is young. When she is old, she goes into a retirement home without guardians or helpers. This is her final destination. Is it this woman who is honored or is it the protected one who is served, honored, preserved and cared for when she gets older? (http://www.darulhadith.com/v2/den-muslimska-kvinnanen-bevarad-parla/)

'Allāmah Rab̄ī' bin Hādī al-Madkhalī is used to confirm that there is a difference between the genders from birth, and God has given men an advantage above women. This is seen for example in the fact that two lambs are slaughtered at the birth of a boy, compared to one for a girl. The urine of girls must be washed away, while it is enough to pour some water over the urine of a boy. Sons inherit twice as much as girls, and women are half witnesses (http: //www.darulhadith.com/v2/skillnaden-mellan-konen-borjar-fran-fodseln/). Al-Madkhalī is critical of al-Ghazzāli due to his views that are apparently considered too liberal. He calls the above-mentioned rulings eternal and just: "All these prescriptions are pure truth, justice and wisdom that are in their right place. When Islam commands these just and eternal prescriptions it does not care about what people with lusts shall think. Islam does not compromise with sick souls and wishes of crazy brains". Here too, we can note the comparison between ideal Islam and the behavior of those considered enemies. Moreover, the stress on justice appears again. Since God is considered to be just, the established Islamic rules must necessarily be just as well.

Sometimes some of the shuyūkh referred to on the website explicitly display dislike of imitation of things considered innovation. One example that is very clear will be presented, even though it may look like it is an attempt at making them look ridiculous, which is not the intention. The example is a comment on the use of the term "ladies" for female restrooms and "male" for male restrooms. Muhammad bin Sālih bin "Uthaymīn states that the word "lady" that was not used by the early Muslims and that it therefore should be erased from the dictionaries, and also on the signs of toilets. He states: "This is a de-evaluation of men. When a man sees that he's just a man while she's a lady he will be offended" (http://www.darulhadith.com/v2/den-tillfangatagna-damen/).

Ibn 'Uthaymin also refers to the Qur'an to validate his opinion that men are better than women:

O my sons! Lo! Allah hath chosen for you the (true) religion; therefore die not save as men who have surrendered (unto Him). (Q2:123)

Ibn 'Uthaymīn concludes that we learn three things from this:

1. The need to obey God;

2. The sons fulfil this duty, calls to Islam and spread Islam to the people;

3. Male gender is better than female gender (http://www.darulhadith.com/v2/den-muslimskakvinnan-en-bevarad-parla/).

A khutbah by Ibn 'Uthaymin is published, which has two aims according to him, where one is to reject equality and the other to remind men about their responsibility concerning the behavior of women:

The first: the stupidity among those who call for equality between the man and the woman, or (hold) that she has the rights equal to the man

The second: I place the responsibility on the guardians when some of their women end up in sin when they take the veil (niqāb) and perfuming easily while going to the stores (http://www. darulhadith.com/v2/ibn-\%c2\%b4uthaymins-fredagspredikan-om-konens-jamstalldhet/).

The above examples should be enough to outline to the reader what views are prevalent on the website concerning gender. There are more examples that could be included, but these ones are representative of the ideology presented on the website, concerning gender issues and views on equality. 


\section{Concluding Comments}

Is the website extremist? From the empirical examples, we can obviously note that gender equality as defined by the Swedish government is not promoted. The view on gender is based on a traditional Islamic understanding of a division of gender roles. Men and women do not have the same opportunities to shape society and their own lives. Women are subservient to men. Women do not have the same opportunities to work or study and they do not have physical integrity. They must cover and stay in their homes. The few examples presented show that the designation "extreme", as a relational concept, is valid to use analytically. However, we may still question whether it is appropriate or not to use the designation.

Using the term extremism to designate an Islamic interpretation may contribute to a stigmatization and generalization of Islam/Muslims. The terminology is in a sense a construction of an "other" (extremist, nondemocratic) as compared to an "us" (democratic). The need to clearly define the benchmark is thus clear. Using such analytical terms with clear definitions should not be avoided. Moreover, avoiding terms that carry negative connotations in a vernacular sense is also not necessarily bringing more analytical clarity. However, analytical terms such as "fundamentalism" and "extremism" may contribute to a more critical and clear analysis. There may be a risk that academics dealing with for example Salafism may take an apologetic or perhaps less critical stance in order not to strengthen Islamophobic attitudes and practices, and therefore avoid using terms such as "extremism" or "fundamentalism", and stress the non-violent approach of some extremist groups, and avoid "difficult questions". We can also ask if we perhaps should simply avoid such potentially sensitive material due to the lack of possibilities to control how our analyses are received and used. Following McCutcheon's critical comments on apologetic scholarship on religion, we can ask ourselves the following question: "if we cannot say something nice about someone, should we just keep our scholarly mouths shut?" (McCutcheon 2006, p. 732).

The above-mentioned differentiation between not-violent activism and non-violent extremism may be useful here. From the empirical presentation, we can conclude that the perspective presented on the website represents a non-violent case of extremism. The group would not be eligible to gain any financial support from the Swedish Agency for Support to Faith Communities due to the Agency's demand of promoting democratic values as criteria for funding. This conclusion does not mean that Salafism by definition is an immediate security threat and a threat to democracy. As seen, the perspectives differ between analysts. Some hold that due to maximalist goals and missionary activities, even non-violent Salafis push their Salafi, as in undemocratic (extremist), agenda. As the introduction showed, the term extremism is used for close-minded and supremacist ideologies - that not necessarily advocate violence. What is certain is that groups that do not promote individual's rights and freedoms, at least not for women (or "infidels") as is the case of the empirical material, is not pursuing a democratic agenda. This is certainly an at least potential social problem (if it would be put into practice). Such an ideology may develop into a real threat to democratic order. If such ideologies function as a "conveyor belt" into other more violently inclined activities, or sympathies, it is worth addressing them critically as well. However, we must also remind ourselves that it is not illegal to be convinced of, for example, the superiority of men over women, or to wish to live a gender segregated life, even though such stances certainly limits a person and may cause segregated enclaves in society. We must also differ between ideas and actions. Ideas are the aspired goals and the actions are the methods to attain the goals (which may be advocated but not necessarily put into practice).

Related to the discussion on the risk of stigmatization, we should also ask whether the view on gender and equality that presented here is unique. Speaking in a generalizing sense, several Islamic interpretations are gender conservative and stress inequality between men and women as a divine given. If we would analyze other religious traditions, we would find similar perspectives as well, so it is not unique to Islam or Muslims. We can find a wide variety of practices and interpretations within all religious traditions. For example, several quite liberal Islamic reinterpretations concerning gender roles and equality develop today among feminist and progressively inclined Muslims (see for 
example (Safi 2003)). We should also note that there are several cases among minority Muslims in many European countries where Muslims (both men and women) do not shake hands with non-mahram of the opposite sex. That does not necessarily mean that they are Salafi, but may simply mean that they follow a rather mainstream Islamic interpretation on gender, but one that does not necessarily lead to demands of segregation and enclavism. In the case of contemporary Salafism, gender conservatism as an ideology, and gender segregation as practice, is the general case following the strict rule on imitation of the sources and the call for a literal reading of the Qur'an and Sunnah. This attitude closes the opportunity to reinterpret the texts or adapt the interpretation to the contextual situation where one lives. The group used as material for this article is no exception to this.

In a Swedish setting, such a Salafi interpretation leads to an ideology of gender segregation and gender inequality, where especially women are subject to control and male dominance. In order to actually implement such a lifestyle, segregation and enclavism is a necessary part of the ideology. The "enemies" mentioned in the empirical presentation are closely surrounding the Salafi minority in such a setting. For Salafis living as minorities in Western countries, the question of gender equality seems to be an important aspect that leads to a clear differentiation between in-groups and out-groups, and as such an important strategy for identity formation and group consolidation. Women gain a strongly symbolic value in such milieus that strive hard to establish group boundaries. After all, Salafis consider themselves "the chosen group" and it is important to know who belongs to the truth, and who does not (Olsson 2016, p. 121). There should therefore be no surprise why equality and gender issues are stressed to such an extent in the material.

As a final note we should also consider that an analysis of websites or publications may say absolutely nothing about practice or reception. We cannot ascertain that somebody accepts these ideas as a norm to live by, or that anyone lives by them. However, it is at least my impression that ideas like this are growing and that they do influence many Muslims. However, more fieldwork and interviews would be necessary to say that without only speculating.

Funding: This research was funded by Myndigheten för Samhällsskydd och Beredskap, grant number 2018-41.

Conflicts of Interest: The author declares no conflicts of interest.

\section{References}

Abou El Fadl, Khaled. 2001. Speaking in God's Name: Islamic Law, Authority and Women. Oxford: Oneworld.

al-Rasheed, Madawi. 2013. A Most Masculine State: Gender, Politics, and Religion in Saudi Arabia. Cambridge: Cambridge University Press.

Bartlett, Jamie, Birdwell Jonathan, and King Michael. 2010. The Edge of Violence: A Radical Approach to Extremism. Available online: http://www.demos.co.uk/files/Edge_of_Violence_-_web.pdf (accessed on 19 November 2018).

Berger, J. M. 2018. Extremism. Cambridge: The MIT Press.

Cesari, Jocelyne. 2009. The Securitisation of Islam in Europe. Challenge Research Paper no. 14, April. Centre for European Policy Studies. Available online: https:/www.ceps.eu/ceps-publications/securitisation-islameurope/ (accessed on 20 February 2020).

Della Vida, Levi G. 2012. Khāaridjites. In Encyclopaedia of Islam, 2nd ed. Edited by Peri Bearman, Thierry Bianquis, C. Edmund Bosworth, Emeri van Donzel and Wolfhart P. Heinrichs. ISBN 9789004161214. 1960-2007. Available online: http://dx.doi.org.ezp.sub.su.se/10.1163/1573-3912_islam_COM_0497 (accessed on 23 August 2018).

Duderija, Adis. 2011a. Constructing a Religiously Ideal 'Believer' and 'Woman' in Islam. Neo-Traditional Salafi and Progressive Muslims' Methods of Interpretation. Basingstoke: Palgrave Macmillan.

Duderija, Adis. 2011b. Neo-Traditional Salafi Qur'an-Sunna Hermeneutics and its Interpretational Implications. Religion Compass, 314-25. [CrossRef]

Extreme. 1986. Webster's Ninth New Collegiate Dictionary. Springfield: Merriam-Webster, p. 44.

Green, Todd H. 2015. The Fear of Islam: An Introduction to Islamophobia in the West. Minneapolis: Fortress Press.

Hoewe, Jennifer, and Brian J. Bowe. 2018. Magic Words or Talking Point? The Framing of 'Radical Islam' in News Coverage and its Effects. Journalism. [CrossRef] 
Inge, Anabel. 2016. The Making of a Salafi Muslim Woman: Paths to Conversion. New York: Oxford University Press. Kruglanski, Arie W., Katarzyna Jasko, Marina Chernikova, Michelle Dugas, and David Webber. 2017. To the Fringe and Back: Violent Extremism and the Psychology of Deviance. American Psychologist 72: 217-30. [CrossRef] [PubMed]

Le Renard, Amélie. 2008. "Only for Women": Women, the State, and Reform in Saudi Arabia. Middle East Journal 62: 610-29. [CrossRef]

Lowe, David. 2017. Prevent Strategies: The Problems Associated in Defining Extremism: The Case of the United Kingdom. Studies in Conflict \& Terrorism 40: 917-33. [CrossRef]

Mandel, David R. 2009. Radicalization: What does it mean? In Home-Grown Terrorism: Understanding and Addressing the Root Causes of Radicalisation among Groups with an Immigrant Heritage in Europe. Edited by Thomas M. Pick, Anne Speckhard and Beatrice Jacuch. Amsterdam: IOS Press, pp. 101-13.

McCutcheon, Russel T. 2006. “It's a Lie. There's No Truth in It! It's a Sin!" On the Limits of the Humanistic Study of Religion and the Costs of Saving Others from Themselves. Journal of the American Academy of Religion 74: 720-50. [CrossRef]

Meijer, Roel, ed. 2009a. Global Salafism: Islam's New Religious Movement. Oxford: Oxford University Press.

Meijer, Roel. 2019b. Reform in Saudi Arabia: The Gender-Segregation Debate. Middle East Policy 17: 80-100. [CrossRef]

Mudde, Cas. 2016. SYRIZA: The Failure of the Populist Promise. Reform and Transition in the Mediterranean. London: Palgrave Macmillan.

Olsson, Susanne. 2016. Minority Jurisprudence in Islam: Muslim Communities in the West. London: I.B.Tauris.

Olsson, Susanne. 2017. Shiah as Internal Others-A Salafi Rejection of the "Rejecters". Islam and Christian Muslim Relations 28: 409-30. [CrossRef]

Olsson, Susanne. 2019. Contemporary Puritan Salafism: A Swedish Case Study. London: Equinox.

Orrenius, Niklas. 2017a. Måste svenska skattepengar gå till saudisk mission? Dagens Nyheter. September 1. Available online: https://www.dn.se/nyheter/sverige/niklas-orrenius-maste-svenska-skattepengar-ga-tillsaudisk-mission/ (accessed on 20 August 2018).

Orrenius, Niklas. 2017b. Svenska shiamuslimer hotas från två håll. Dagens Nyheter. May 26. Available online: https://www.dn.se/nyheter/sverige/niklas-orrenius-svenska-shiamuslimer-hotas-fran-tva-hall/ (accessed on 20 August 2018).

Pickthall, Marmaduke. 1930. The Meaning of the Glorious Koran: An Explanatory Translation by Marmaduke Pickthall. London: George Allen and Unwin Ltd.

Roex, Ineke. 2004. Should we be scared of all Salafists in Europe? A Dutch Case Study. Perspectives on Terrorism 8: 51-63.

Safi, Omid, ed. 2003. Progressive Muslims: on Justice, Gender and Pluralism. Oxford: Oneworld Publications.

Schmid, Alex P. 2014. Violent and Non-Violent Extremism: Two Sides of the Same Coin? The International Centre for Counter-Terrorism-The Hague 5. [CrossRef]

Sedgwick, Mark. 2010. The Concept of Radicalisation as a Source of Confusion. Terrorism and Political Violence 22: 479-94. [CrossRef]

Swedish Agency for Support to Faith Communities. n.d. Available online: http://www.myndighetensst.se/om-oss/ in-english.html (accessed on 20 August 2018).

Swedish Government. n.d.a. Available online: https://www.government.se/government-policy/gender-equality/ (accessed on 20 August 2018).

Swedish Government. n.d.b. Available online: https://www.government.se/government-policy/gender-equality/ goals-and-visions/ (accessed on 20 August 2018).

Wagemakers, Joas. 2012. "Seeders" and "postponers"? An analysis of the "Khawarij" "Murji'a" labels in polemical debates between quietists and jihadi-Salafis. In Contextualising Jihadi Thought. Edited by Jevaan Deol and Zaheer Kazmi. London: Hurst, pp. 145-64.

Wagemakers, Joas. 2008. Framing the 'Threat to Islam': Al-Wala' wa al-Bara' in Salafi Discourse. Arab Studies Quarterly 30: 1-22.

Wagemakers, Joas. 2009. The Transformation of a Radical Concept: Al-wala' wa-l-bara' in the Ideology of Abu Muhammad al-Maqdisi. In Global Salafism: Islam's New Religious Movement. Edited by Roel Meijer. Oxford: Oxford University Press. 
Wagemakers, Joas. 2016. Salafi scholarly views on gender-mixing (ikthilāț) in Saudi Arabia. Orient German Journal for Politics, Economics and Culture of the Middle East 57: 40-51.

Wiktorowicz, Quintan. 2001. The Management of Islamic Activism: Salafis, the Muslim Brotherhood, and State Power in Jordan. New York: State University of New York Press.

Wiktorowicz, Quintan. 2006. Anatomy of the Salafi movement. Studies in Conflict and Terrorism 29: 207-39. [CrossRef]

(C) 2020 by the author. Licensee MDPI, Basel, Switzerland. This article is an open access article distributed under the terms and conditions of the Creative Commons Attribution (CC BY) license (http://creativecommons.org/licenses/by/4.0/). 